\title{
Food restriction regulates adipose-specific cytokines in pituitary gland but not in hypothalamus
}

\author{
Glen Wiesner $^{1,4}$, Barbara A Morash ${ }^{1,2}$, Ehud Ur ${ }^{1,2}$ and \\ Michael Wilkinson ${ }^{1,2,3}$ \\ 'Department of Obstetrics and Gynaecology, Faculty of Medicine, Dalhousie University, 5980 University Avenue, Halifax, NS, Canada B3J 3G9 \\ ${ }^{2}$ Division of Endocrinology, Faculty of Medicine, Dalhousie University, Halifax, NS, Canada B3J 2Y9 \\ ${ }^{3}$ Department of Physiology and Biophysics, Faculty of Medicine, Dalhousie University, Halifax, NS, Canada B3H 4H7 \\ ${ }^{4}$ Human Neurotransmitter Laboratory, Baker Medical Research Institute, Melbourne, VIC, Australia \\ (Requests for offprints should be addressed to M Wilkinson; Email: mwilk@dal.ca)
}

\begin{abstract}
White adipose tissue is now recognized as the source of a growing list of novel adipocyte-specific factors, or adipokines. These factors regulate energy homeostasis, including the response to food deprivation. We hypothesized that the brain and pituitary gland would also express adipokines and their regulatory factors and subsequently demonstrated that the rodent brain-pituitary system expresses mRNA and protein for leptin and resistin. We now report that the adipokines FIAF and adiponutrin, as well as the nuclear hormone receptor PPAR $\gamma$, are expressed in pituitary, brain and adipose tissue. In pituitary gland, $24 \mathrm{~h}$ of food restriction reduced PPAR $\gamma$ expression by $54 \%$ whereas both adiponutrin and FIAF were increased 1.7 and $2 \cdot 3$
\end{abstract}

fold, respectively. These changes in expression were similar to those observed in fat, except for adiponutrin, which by contrast is dramatically reduced $95 \%$ by fasting. Furthermore, whereas PPAR $\gamma 2$ is the main isoform affected by fasting in adipose tissue, our data suggest that only PPAR $\gamma 1$ is present and downregulated by fasting in pituitary tissue. In contrast to the sensitivity of pituitary tissue to the effects of fasting, no significant change in expression was observed in basal hypothalamus for any of the genes studied. Overall, our data suggest that pituitaryderived adipokines may play an unexpected role in the neuroendocrine regulation of energy homeostasis.

Journal of Endocrinology (2004) 180, R1-R6

\section{Introduction}

Classically viewed as a passive energy storage depot, white adipose tissue (WAT) is now recognized as a source of numerous secreted factors which play an important role in mammalian physiology, and in particular, energy homeostasis (Ahima \& Flier 2000, Fruhbeck et al. 2001, Trayhurn \& Beattie 2001). In the last decade, a growing list of novel, adipocyte-secreted factors, or adipokines, were discovered. This list includes, but is not limited to, leptin (Himms-Hagen 1999), resistin (Banerjee \& Lazar 2003), adiponectin/acrp30 (Berg et al. 2002), FIAF (fasting-induced adipose factor) (Kersten et al. 2000), and adiponutrin (Baulande et al. 2001, Polson \& Thompson 2003). These adipokines regulate glucose and fatty acid homeostasis, appetite control, energy expenditure, and the response to starvation. Hence, the perception of WAT function has changed significantly to accommodate its emerging role as an endocrine organ (Trayhurn \& Beattie 2001).

A common characteristic of adipokines is their purported adipose-specific expression and release. Leptin, although inarguably produced chiefly by adipocytes, is expressed by many peripheral tissues including the human placenta, stomach, and skeletal muscle (Ahima \& Flier 2000). In addition we identified leptin mRNA and protein expression in the rodent brain and pituitary gland (Morash et al. 1999, Wilkinson et al. 2000, Ur et al. 2002). Another supposedly adipose-specific factor, resistin, is also found in the mouse brain and pituitary gland (Morash et al. 2002). Furthermore, both resistin (Song et al. 2002) and leptin (De Vos et al. 1996) are target genes for the transcription factor peroxisome proliferator-activated receptor gamma (PPAR $\gamma)$, the presence of which has been recently demonstrated in anterior pituitary cells (Heaney et al. 2003). Similar to the adipokines, PPAR $\gamma$ is 
Table 1 Primer sequences and PCR conditions

\begin{tabular}{|c|c|c|c|c|c|}
\hline & Sequence $5^{\prime}-3^{\prime}$ & $\begin{array}{l}\text { Product } \\
\text { Size }(b p)\end{array}$ & $\begin{array}{l}\text { Anneal } \\
\left({ }^{\circ} \mathrm{C}\right)\end{array}$ & $\begin{array}{l}\text { Cycles } \\
\text { Pit/Fat }\end{array}$ & Reference \\
\hline \multicolumn{6}{|l|}{ Primer } \\
\hline \multicolumn{6}{|l|}{ Adiponutrin } \\
\hline Antisense & GGCAGATGTCATGCTCACCG & 551 & 60 & $29 / 25$ & (Polson and Thompson 2003) \\
\hline \multicolumn{6}{|l|}{ FIAF } \\
\hline $\begin{array}{l}\text { Sense } \\
\text { Antisense }\end{array}$ & $\begin{array}{l}\text { GGAGCGGCACAGTGGACTIT } \\
\text { TACCCTITACGСTCCTGCC }\end{array}$ & 548 & 58 & $29 / 25$ & $($ Yoon et al. 2000)* \\
\hline \multicolumn{6}{|l|}{$\operatorname{PPAR} \gamma(1 \& 2)$} \\
\hline Sense & TGATATCGACCAGCTGAACC & \multirow{2}{*}{704} & \multirow{2}{*}{57} & \multirow{2}{*}{$32 / 26$} & \multirow{2}{*}{ (Yang et al. 1999) } \\
\hline \multicolumn{2}{|l|}{ PPAR $\gamma 2$} & & & & \\
\hline Sense & GCTGATGCACTGССТАTGAG & \multirow[b]{2}{*}{538} & \multirow[b]{2}{*}{57} & \multirow[b]{2}{*}{$40 / 29$} & \multirow[b]{2}{*}{-} \\
\hline Antisense & TCTGAAACCGACAGTACTGAC & & & & \\
\hline
\end{tabular}

Pit - pituitary gland. *Primer sequence modified from original reference.

predominantly expressed in adipose tissue where it is implicated in adipocyte differentiation, lipid storage and glucose homeostasis (Kliewer et al. 1994).

Thus, given the presence of resistin, leptin and PPAR $\gamma$ in pituitary tissue, we hypothesized that other adipokines should also be expressed in the pituitary where they may play a role in the neuroendocrine regulation of energy balance. We show here that this hypothesis is correct and, moreover, that pituitary adipokine gene expression is specifically sensitive to food availability, whereas hypothalamic expression is unaffected.

\section{Materials and Methods}

Animals

Pubertal CD1 mice (male; 22-24 g; age 30-32 days) were obtained from Charles River Breeding Farms (Quebec, Canada), maintained under a photoperiod of $14 \mathrm{~h}$ light: $10 \mathrm{~h}$ darkness (lights on: $0700 \mathrm{~h}$ ) and given free access to Purina Rat Chow and drinking water. For fasting studies, food was removed in the late morning for a $24 \mathrm{hr}$ period. The experimental protocol was reviewed and approved by the Dalhousie University Committee on Laboratory Animals. Mice were killed by decapitation and samples of frontal cerebral cortex, basal hypothalamus, and visceral (epididymal) fat were dissected and frozen in liquid nitrogen. The pituitary gland was removed intact (anterior plus posterior).

\section{RNA isolation and semi-quantitative RT-PCR analysis}

Total RNA was isolated from brain and pituitary using the RNeasy mini kit (Qiagen) and from adipose tissue using Trizol reagent (Gibco; Burlington, ON, USA). The RNA was DNase treated using the RNase-free DNase kit (Qiagen). RNA (1 $\mu \mathrm{g}$ for brain and pituitary; $0.35 \mu \mathrm{g}$ for adipose tissue) was denatured at $65{ }^{\circ} \mathrm{C}$ for $5 \mathrm{~min}$ and reverse transcribed in a final volume of $30 \mu \mathrm{l}$ using Omniscript reverse transcriptase (Qiagen) at $37^{\circ} \mathrm{C}$ for one hour. Semi-quantitative PCR amplification was performed using intron-flanking primers and HotStarTaq DNA polymerase (Qiagen), as previously described (Morash et al. 2002). Reactions were normalised by evaluating the house-keeping transcript $18 \mathrm{~S}$ using commercial primers (Classic 18S primers; Ambion). The sequences of the primers and PCR reaction conditions are outlined in Table 1. For PPAR $\gamma$, two sets of primers were utilised which detect either general PPAR $\gamma$ expression (isoforms 1 and 2) or PPAR $\gamma 2$ specifically. For RT-PCR analysis of pituitary tissue, each 'n' value represents tissue pooled from 2 mice.

\section{Cloning and sequencing of PCR products}

Total RNA from pituitary and gonadal fat was reverse transcribed and PCR-amplified as described above. Portions of the resulting PCR reaction were cloned into pGEM-T Easy (Promega; Madison, WI, USA) and transformed into E.coli. Individual transformants were sent for sequence analysis to Cortec DNA Service Laboratories Inc. (Kingston, ON). The PCR-generated amplicons were found to be $100 \%$ identical to the corresponding regions of the genes of interest.

\section{Northern blot analysis}

Tissues (hypothalamus, cortex, pituitary and visceral fat) were collected from 40 male CD1 mice at postnatal day (PD) 28 for isolation of total RNA using Qiagen RNeasy midi kits (brain/pituitary) or Trizol reagent (Gibco, BRL). Poly A+ RNA was isolated from the total RNA using Oligotex mRNA mini kit (Qiagen). Approximately 5-7 $\mu \mathrm{g}$ of poly A+ RNA was analyzed by Northern 
analysis using the NorthernMax kit (Ambion). RNA was separated by agarose gel electrophoresis and subsequently transferred to BrightStar-Plus nylon membrane (Ambion). Probes for adiponutrin and FIAF were generated by PCR amplification using the primers outlined in Table 1 . Amplicons were isolated by agarose gel electrophoresis, purified (QIAquick gel extraction kit; Qiagen) and quantitated. Probes were radiolabeled with $\alpha \mathrm{P}^{32} \mathrm{dCTP}$ using Rediprime II random prime labelling system (Amersham). The labeled probes were separated from un-incorporated radionucleotides using Probe Quant G-50 micro columns (Amersham). The nylon blot was prehybridized in $13 \mathrm{ml}$ of hybridization solution at $42{ }^{\circ} \mathrm{C}$ for $1 \mathrm{~h}$. Probes were denatured by boiling for $5 \mathrm{~min}$, quick chilled for $5 \mathrm{~min}$ and added to the prehybridized nylon blot (approximately $1 \times 10^{6}$ c.p.m. $/ \mathrm{ml}$ hybridization buffer). The blot was hybridized at $42{ }^{\circ} \mathrm{C}$ overnight and subsequently washed twice for $5 \mathrm{~min}$ in $2 \times \mathrm{SSC} / 0 \cdot 1 \% \mathrm{SDS}$ at room temperature followed by two 15 minute washes $\left(42{ }^{\circ} \mathrm{C}\right)$ in $0 \cdot 1 \times$ SSC/0.1\%SDS. Subsequently, the blot was exposed for 6-18 h to X-ray film (Eastman Kodak).

\section{Statistical analysis}

Data were analyzed by Student's $t$-test and are reported as mean \pm S.E.M. Significance was set at $P<0 \cdot 05$.

\section{Results}

Adipokine and PPAR $m$ RNA expression in pituitary and brain tissue

Adiponutrin, FIAF and PPAR $\gamma$ mRNA expression was assessed by RT-PCR analysis and products of the expected sizes were reproducibly detected in fat, hypothalamus, cerebral cortex and whole pituitary gland (Fig. 1A). As expected, abundant expression was observed in adipose tissue for all genes studied. Moreover, FIAF, adiponutrin, and PPAR $\gamma$ mRNA were all readily detectable in brain and pituitary tissues, albeit at lower levels than adipose tissue. Of note is the observation that only general PPAR $\gamma$ (non-isoform specific) expression was observed in brain and pituitary, with specific PPAR $\gamma 2$ expression not detected after 40 PCR cycles. In adipose tissue, specific PPAR $\gamma 2$ expression was less abundant than general PPAR $\gamma$. PCR product identities were confirmed by sequencing and comparison with the GenBank database.

Using probes generated in the RT-PCR experiments, adiponutrin, and FIAF expression was also assessed by Northern analysis in pituitary, brain and adipose tissue (Fig. 1B). As expected, high levels of expression were observed in visceral fat. Again, adiponutrin and FIAF mRNA were readily detected in brain and pituitary gland. Northern analysis for PPAR $\gamma$ mRNA was not performed

\section{A. RT-PCR}

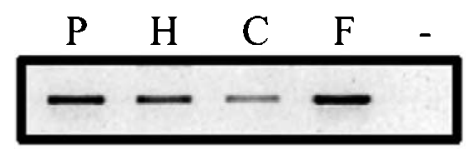

Adiponutrin

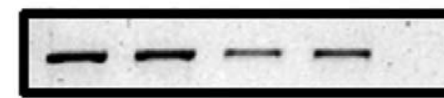

\section{FIAF}

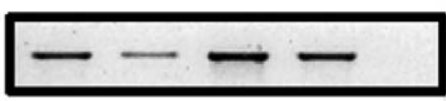

PPAR- $\gamma(1+2)$

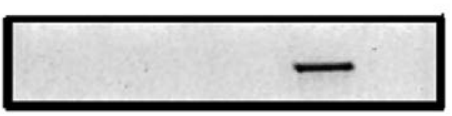

PPAR- $\gamma(2)$

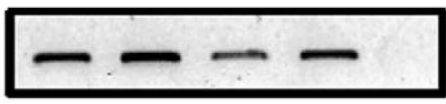

$18 \mathrm{~S}$

\section{B. Northern Analysis}

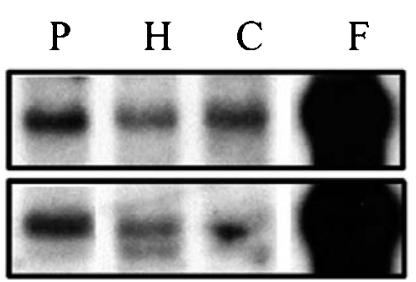

\section{Adiponutrin $(3.2 \mathrm{~kb})$}

\author{
FIAF $(1.8 \mathrm{~kb})$
}

Figure 1 (A) RT-PCR analysis of adipokine gene expression in male (PD28) CD1 mouse pituitary (P), hypothalamus $(\mathrm{H})$, cerebral cortex $(C)$ and visceral fat (F) tissue. PCR parameters and amplicon sizes are outlined in Table 1. No PCR products were detected in the negative (-) controls, which were performed by omission of reverse transcriptase. Figure 1 (B) Northern analysis of adipokine gene expression in cerebral cortex $(\mathrm{C})$, hypothalamus $(\mathrm{H})$, pituitary $(\mathrm{P})$ and visceral fat $(\mathrm{F})$ tissue from male (PD28) mice. Each lane contains approximately 5-7 $\mu \mathrm{g}$ of poly A+ mRNA. The expected size of the native mRNA transcript is indicated.

because of the existing strong evidence of expression in pituitary and brain (Rohn et al. 2001, Heaney et al. 2003).

Effects of fasting on adipokine and PPAR $\mathrm{mRNA}$ in pituitary and adipose tissue

In two separate experiments, we used semi-quantitative RT-PCR to determine the effect of a 24-h fast on PPAR $\gamma$, FIAF, and adiponutrin mRNA expression (Fig 2). In adipose tissue, fasting resulted in a $2 \cdot 5$-fold increase in FIAF expression $(P<0.025)$, whereas adiponutrin was dramatically reduced by $95 \%(P<0 \cdot 005)$. Fasting also caused significant reductions in PPAR $\gamma 2$ expression in fat $(61 \%, P<0 \cdot 01)$ but had no effect on PPAR $\gamma(1$ and 2$)$. In pituitary tissue, fasting also resulted in marked alterations in expression, however some differences were observed when compared with fat. In parallel with adipose tissue, 


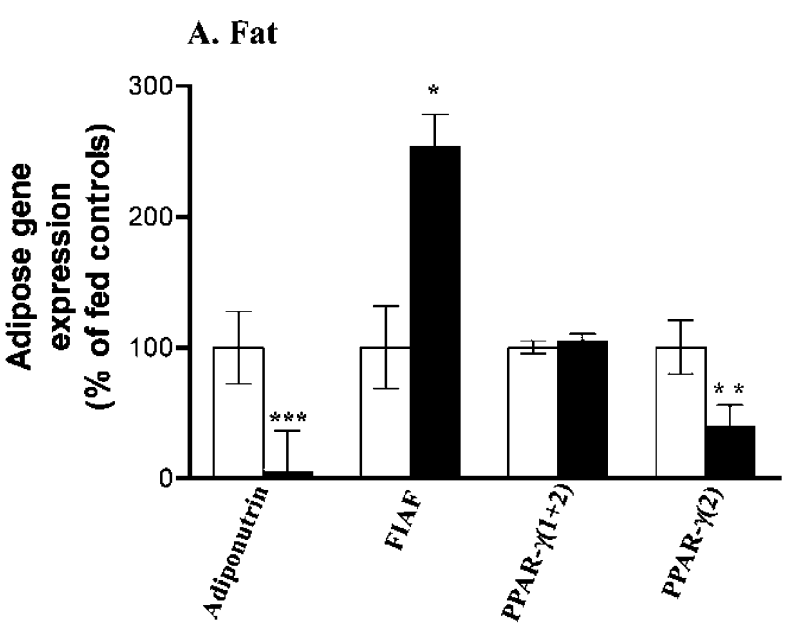

\section{B. Pituitary}

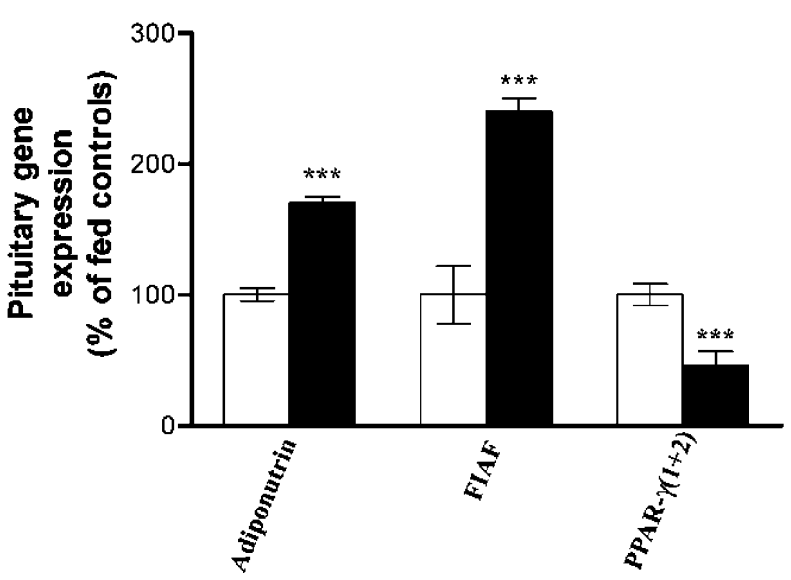

Figure 2 Effect of $24 \mathrm{~h}$ of fasting on adipose (A) and pituitary (B) adipokine mRNA expression. Semi-quantitative RT-PCR was used to analyse changes in gene expression. Data are represented as percentage change (mean \pm S.E.M.) based on fed control groups (control=clear bars, fasted $=$ solid bars). Cumulative data represent the pooled result of two separate fasting experiments $(n=7$ for adipose tissue, except PPAR $\gamma 1 \& 2$ where $n=3 ; n=8$ for pituitary tissue). For pituitary tissue, each ' $n$ ' represents two pooled pituitary glands. ${ }^{*} P<0 \cdot 025,{ }^{* *} P<0 \cdot 01,{ }^{* * *} P<0 \cdot 005$ (by $t$-test).

FIAF expression was increased 2.4-fold in pituitary tissue $(P<0.005)$, but unlike adipose tissue, pituitary adiponutrin expression was significantly increased $(1.7$ fold; $P<0 \cdot 005)$. Pituitary PPAR $\gamma(1$ and 2$)$ expression was reduced by fasting by $54 \%(P<0 \cdot 005)$. Since PPAR $\gamma 2$ expression was undetectable in pituitary, the change in expression observed putatively reflects that of PPAR $\gamma 1$. In contrast to the effect of fasting on gene expression in pituitary and fat tissue, no effect was observed in basal hypothalamus $(n=5)$ for any of the genes studied (adipo- nutrin: $P=0 \cdot 47$; FIAF: $P=0 \cdot 16 ; \operatorname{PPAR} \gamma(1$ and 2$)$ : $P=0 \cdot 29$; data not shown).

\section{Discussion}

In previous studies we tested the hypothesis that the brain and pituitary gland should express the adipokines leptin and resistin. This hypothesis proved to be correct (Morash et al. 1999, 2002), and in the case of leptin was independently confirmed (Jin et al. 2000, Beretta et al. 2002, Ehrhardt et al. 2002). Thus, brain-derived leptin could be the endogenous ligand for some populations of central leptin receptors. Receptors for resistin have not yet been reported, but resistin is regulated via PPAR $\gamma$ and C/EBPa (Song et al. 2002), both of which are found in brain and pituitary (Cardinaux et al. 2000, Rohn et al. 2001, Day et al. 2003, Heaney et al. 2003). Our detection of resistin mRNA and protein in brain and pituitary therefore suggests a role for resistin in the neuroendocrine system. We have extended this logic to demonstrate, for the first time, the expression of the novel adipokines adiponutrin and FIAF in mouse brain and pituitary. Furthermore, we have shown that these genes may be differentially regulated in fat, pituitary and brain tissue.

Adiponutrin is a transmembrane protein which, although not secreted, shows similar characteristics to other adipokines (Baulande et al. 2001) and is reportedly expressed solely in white and brown adipose tissue. Adiponutrin mRNA levels are elevated in fat from obese $\mathrm{fa} / \mathrm{fa}$ rats whereas fasting dramatically reduces mRNA levels (Baulande et al. 2001, Polson \& Thompson 2003). We confirmed the fasting-induced decline in adipose adiponutrin mRNA but also demonstrated an unexpected increase of gene expression in pituitary tissue. The reason for the fasting-induced increase in pituitary expression is unclear, however it indicates that pituitary adiponutrin expression may be regulated by mechanisms distinct from those operating in adipocytes.

FIAF (fasting-induced adipose factor) is a member of the angiopoietin family of secreted proteins (Kersten et al. 2000, Yoon et al. 2000) and is predominantly localized to adipose tissue. FIAF is reported to be aPAR $\gamma$ target gene in adipose tissue but, by contrast, a $\operatorname{PPAR} \alpha$ target gene in the liver (Kersten et al. 2000, Yoon et al. 2000). As its name implies, FIAF is increased in response to fasting in adipose tissue (Kersten et al. 2000, Yoon et al. 2000). We confirmed this observation and showed that pituitary FIAF mRNA is similarly sensitive to food restriction. In fat, however, leptin-induced appetite suppression does not result in increased FIAF mRNA (Yoon et al. 2000). This raises the possibility that upregulation of FIAF expression is inhibited by leptin.

$\operatorname{PPAR} \gamma$ is a ligand-activated transcription factor belonging to the nuclear hormone receptor superfamily 
(Zhu et al. 1995). Alternative promoter usage and differential splicing of the PPAR $\gamma$ gene results in two isoforms, $\gamma 1$ and $\gamma 2$, which differ by 30 additional amino acids at the N-terminal of $\gamma 2$ (Zhu et al. 1995). PPAR $\gamma$ expression is largely restricted to adipose tissue and large intestine (Kliewer et al. 1994, Escher et al. 2001) with variations in the relative abundance and distribution of the $\gamma 1$ and $\gamma 2$ isoforms (Escher et al. 2001). Recently, PPAR $\gamma$ immunoreactivity was reported in normal corticotrophic pituitary cells with abundant expression observed in pituitary tumours (Heaney et al. 2003). In the present study we demonstrate for the first time mRNA expression of $\operatorname{PPAR} \gamma$ in normal pituitary tissue, our data suggesting that this is limited to the PPAR $\gamma 1$ isoform. The effects of high affinity $\operatorname{PPAR} \gamma$ ligands such as the insulin-sensitizing thiazolidinediones (TZDs) implicate $\operatorname{PPAR} \gamma$ in insulin pathways (Wang \& Tafuri 2003). Our data, that pituitary gland $\operatorname{PPAR} \gamma$ mRNA is sensitive to food restriction, suggest an additional possible target for TZDs and insulin. Indeed, insulin receptors and proteins thought to be involved in key steps of post-receptor signal transduction (e.g. IRS-1) are widely present in pituitary and brain (Unger \& Betz 1998), indicating a possible link between a peripheral metabolic signal (insulin) and neuroendocrine pathways involving adipokines.

The lack of effect of food restriction on basal hypothalamic expression for any of the genes studied was unexpected. The hypothalamic arcuate nucleus is accepted to be a key target for hormones such as leptin and insulin in the control of energy homeostasis (Niswender \& Schwartz 2003). It is possible that our dissection of the basal hypothalamus might conceal changes in mRNA expression within smaller, discrete nuclei. The application of in situ hybridization analysis to this problem is required. Nonetheless, the apparently specific effect of fasting on pituitary gene expression is intriguing. There is a remarkable convergence of adipokine gene expression with leptin and insulin signaling pathways in the anterior pituitary (Unger \& Betz 1998, Horsch \& Kahn 1999, Gautron et al. 2002). It is feasible that pituitary adipokine expression serves as a link between peripheral metabolic signals and the regulation of pituitary hormone secretion. In keeping with this supposition, preliminary data from our laboratory reveal that ACTH-secreting AtT20 cells abundantly express adiponutrin and PPAR $\gamma$ mRNA (Wiesner et al. 2003).

In summary, we report that multiple adipose factors are expressed in pituitary tissue and brain, and that their mRNA levels in pituitary are sensitive to fasting. The presence of PPAR $\gamma$ and other novel adipose-related transcription factors in pituitary gland and brain indicate the capacity for regulation of adipokine expression in these tissues. The exact role of these adipokines in brainpituitary function remains to be elucidated, though our data suggest they may be implicated in the neuroendocrine response to starvation.

\section{Acknowledgements}

Financial support was from NSHRF (M W and E U) and a Faculty of Medicine Development Grant (M W and E U). Dr Morash was supported by an Isaac Walton Killam Research Associateship and Dr Wiesner by a National Heart Foundation of Australia post-doctoral fellowship. We are grateful to Jeremy Roy and Janet Baker for their help.

\section{References}

Ahima RS \& Flier JS 2000 Leptin. Annual Review of Physiology 62 413-437.

Banerjee RR \& Lazar MA 2003 Resistin: molecular history and prognosis. Journal of Molecular Medicine 81 218-226.

Baulande S, Lasnier F, Lucas M \& Pairault J 2001 Adiponutrin, a transmembrane protein corresponding to a novel dietary- and obesity-linked mRNA specifically expressed in the adipose lineage. Journal of Biological Chemistry 276 33336-33344.

Beretta E, Dube MG, Kalra PS \& Kalra SP 2002 Long-term suppression of weight gain, adiposity, and serum insulin by central leptin gene therapy in prepubertal rats: effects on serum ghrelin and appetite-regulating genes. Pediatric Research 52 189-198.

Berg AH, Combs TP \& Scherer PE 2002 ACRP30/adiponectin: an adipokine regulating glucose and lipid metabolism. Trends in Endocrinology and Metabolism 13 84-89.

Cardinaux JR, Allaman I \& Magistretti PJ 2000 Pro-inflammatory cytokines induce the transcription factors C/EBPbeta and C/EBPdelta in astrocytes. Glia 29 91-97.

Day RN, Voss TC, Enwright JF 3rd, Booker CF, Periasamy A \& Schaufele F 2003 Imaging the localized protein interactions between Pit-1 and the CCAAT/enhancer binding protein alpha in the living pituitary cell nucleus. Molecular Endocrinology 17 333-345.

De Vos P, Lefebvre AM, Miller SG, Guerre-Millo M, Wong K, Saladin R, Hamann LG, Staels B, Briggs MR \& Auwerx J 1996 Thiazolidinediones repress ob gene expression in rodents via activation of peroxisome proliferator-activated receptor gamma. Journal of Clinical Investigation 98 1004-1009.

Ehrhardt RA, Bell AW \& Boisclair YR 2002 Spatial and developmental regulation of leptin in fetal sheep. American Journal of Physiology. Regulatory, Integrative and Comparative Physiology 282 R1628-R1635.

Escher P, Braissant O, Basu-Modak S, Michalik L, Wahli W \& Desvergne B 2001 Rat PPARs: quantitative analysis in adult rat tissues and regulation in fasting and refeeding. Endocrinology 142 4195-4202.

Fruhbeck G, Gomez-Ambrosi J, Muruzabal FJ \& Burrell MA 2001 The adipocyte: a model for integration of endocrine and metabolic signaling in energy metabolism regulation. American Journal of Physiology. Endocrinology and Metabolism 280 E827-E847.

Gautron L, Lafon P, Chaigniau M, Tramu G \& Laye S 2002 Spatiotemporal analysis of signal transducer and activator of transcription 3 activation in rat brain astrocytes and pituitary following peripheral immune challenge. Neuroscience 112 717-729.

Heaney AP, Fernando M \& Melmed S 2003 PPAR-gamma receptor ligands: novel therapy for pituitary adenomas Journal of Clinical Investigation 111 1381-1388.

Himms-Hagen J 1999 Physiological roles of the leptin endocrine system: differences between mice and humans. Critical Reviews in Clinical Laboratory Sciences 36 575-655.

Horsch D \& Kahn CR 1999 Region-specific mRNA expression of phosphatidylinositol 3-kinase regulatory isoforms in the central nervous system of C57BL/6J mice. Journal of Comparative Neurology 415 105-120. 
Jin L, Zhang S, Burguera BG, Couce ME, Osamura RY, Kulig E \& Lloyd RV 2000 Leptin and leptin receptor expression in rat and mouse pituitary cells. Endocrinology 141 333-339.

Kersten S, Mandard S, Tan NS, Escher P, Metzger D, Chambon P, Gonzalez FJ, Desvergne B \& Wahli W 2000 Characterization of the fasting-induced adipose factor FIAF, a novel peroxisome proliferator-activated receptor target gene. Journal of Biological Chemistry 275 28488-28493.

Kliewer SA, Forman BM, Blumberg B, Ong ES, Borgmeyer U, Mangelsdorf DJ, Umesono K \& Evans RM 1994 Differential expression and activation of a family of murine peroxisome proliferator-activated receptors. PNAS 91 7355-7359.

Morash B, Li A, Murphy PR, Wilkinson M \& Ur E 1999 Leptin gene expression in the brain and pituitary gland. Endocrinology 140 5995-5998.

Morash BA, Wilkinson D, Ur E \& Wilkinson M 2002 Resistin expression and regulation in mouse pituitary. FEBS Letters $\mathbf{5 2 6}$ $26-30$.

Niswender KD \& Schwartz MW 2003 Insulin and leptin revisited: adiposity signals with overlapping physiological and intracellular signaling capabilities. Frontiers in Neuroendocrinology 24 1-10.

Polson DA \& Thompson MP 2003 Adiponutrin mRNA expression in white adipose tissue is rapidly induced by meal-feeding a highsucrose diet. Biochemical and Biophysical Research Communications 301 261-266.

Rohn TT, Wong SM, Cotman CW \& Cribbs DH 2001 15-deoxydelta12,14-prostaglandin J2, a specific ligand for peroxisome proliferator-activated receptor-gamma, induces neuronal apoptosis. Neuroreport 12 839-843.

Song H, Shojima N, Sakoda H, Ogihara T, Fujishiro M, Katagiri H, Anai M, Onishi Y, Ono H, Inukai K et al. 2002 Resistin is regulated by $\mathrm{C} / \mathrm{EBPs}$, PPARs, and signal-transducing molecules. Biochemical and Biophysical Research Communications 299 291-298.
Trayhurn P \& Beattie JH 2001 Physiological role of adipose tissue: white adipose tissue as an endocrine and secretory organ. Proceedings of the Nutrition Society 60 329-339.

Unger JW \& Betz M 1998 Insulin receptors and signal transduction proteins in the hypothalamo-hypophyseal system: a review on morphological findings and functional implications. Histology and Histopathology 13 1215-1224.

Ur E, Wilkinson DA, Morash BA \& Wilkinson M 2002 Leptin immunoreactivity is localized to neurons in rat brain. Neuroendocrinology 75 264-272.

Wang M \& Tafuri S 2003 Modulation of PPARgamma activity with pharmaceutical agents: Treatment of insulin resistance and atherosclerosis. Journal of Cellular Biochemistry 89 38-47.

Wiesner G, Morash B, Roy J, Ur E \& Wilkinson M 2003 Adiponutrin gene expression in mouse brain and pituitary: regulation by fasting. Society for Neuroscience Abstracts 29 831.13.

Wilkinson M, Morash B \& Ur E 2000 The brain is a source of leptin. Frontiers of Hormone Research 26 106-125.

Yang T, Michele DE, Park J, Smart AM, Lin Z, Brosius FC 3rd, Schnermann JB \& Briggs JP 1999 Expression of peroxisomal proliferator-activated receptors and retinoid $\mathrm{X}$ receptors in the kidney. American Journal of Physiology 277 F966-F973.

Yoon JC, Chickering TW, Rosen ED, Dussault B, Qin Y, Soukas A, Friedman JM, Holmes WE \& Spiegelman BM 2000 Peroxisome proliferator-activated receptor gamma target gene encoding a novel angiopoietin-related protein associated with adipose differentiation Molecular and Cellular Biology 20 5343-5349.

Zhu Y, Qi C, Korenberg JR, Chen XN, Noya D, Rao MS \& Reddy JK 1995 Structural organization of mouse peroxisome proliferatoractivated receptor gamma (mPPAR gamma) gene: alternative promoter use and different splicing yield two mPPAR gamma isoforms. PNAS 92 7921-7925. 